\title{
Bahasa Indonesia as Official National Language: The Legal Aspect of Presidential Regulation Number 63 of 2019
}

\author{
Muhammad Adji Rahardian Utama ${ }^{1} \bullet$ \\ 'Progressive Law Forum, Semarang, Indonesia \\ ⓐdji.info@gmail.com
}

\begin{abstract}
Indonesia as an independent and sovereign country that has now reached the age of 74 th of the independence itself. As an independent and sovereign country, Indonesia has the official language of its own country, the Bahasa Indonesia that has been recognized by the world. The use of Bahasa Indonesia is also important in its use and application in the life of national and state of the day in Indonesian society itself as stipulated by the Law of the Republic of Indonesia Number 24 Year 2009 about the flags, languages, and emblems of the state, and national anthem. Pursuant to Chapter 1 of Article 1 of Paragraph 2 of the Law of the Republic of Indonesia number 24 year 2009 states that the unitary State language of the Republic of Indonesia hereinafter referred to as Bahasa Indonesia is the official national language used in all Unitary State territory of the Republic of Indonesia. So it can be said that Bahasa Indonesia is a vital thing in this Republic of Indonesia unitary state.
\end{abstract}

Keywords: Bahasa Indonesia; National Language; Legal Aspect; Presidential Regulation 63/2019

\section{Introduction}

Indonesia as an independent and sovereign country that has now reached the age of $74^{\text {th }}$ of the independence itself. As an independent and sovereign country, Indonesia has the official language of its own country, the Bahasa Indonesia that has been recognized by the world. The use of Bahasa Indonesia is also important in its use and application in the life of national and state of the day in Indonesian society itself as stipulated by the Law of the Republic of Indonesia Number 24 Year 2009 about the flags, languages, and emblems of the state, and national anthem. Pursuant to Chapter 1 of Article 1 of Paragraph 2 of the Law of the
Republic of Indonesia number 24 year 2009 states that the unitary State language of the Republic of Indonesia hereinafter referred to as Bahasa Indonesia is the official national language used in all Unitary State territory of the Republic of Indonesia. So, it can be said that Bahasa Indonesia is a vital thing in this Republic of Indonesia unitary state (Art 1 par (2) Law Number 24 of 2009 concerning Flag, Language and Emblem of the Country and National Anthem).

Then what about the use of foreign language itself in this Unitary Republic of Indonesia. Referring back to the law of the Republic of Indonesia Number 24 of 2009 Chapter 1 The General Provisions of Article 1 Paragraph 7 which reads a foreign language is a language other 
than Bahasa Indonesia and regional language (Art 1 par (7) Law Number 24 of 2009 concerning Flag, Language and Emblem of the Country and National Anthem) and also in Article 1 Paragraph 6 which reads regional language is language used by generations of Indonesians in areas in the territory of the Unitary State of the Republic of Indonesia. So, the bias is said that in Indonesia, there are many languages that vary from local language, foreign language, and Bahasa Indonesia as official national language.

\section{Result and Discussion}

\section{A. Bahasa Indonesia as National Language: What Does it Means?}

President Joko Widodo signed Presidential Regulation No. 63 of 2019 on the use of Bahasa Indonesia on September 30, 2019. In such rules, state officials including presidents and vice presidents are required to use Bahasa Indonesia in an official speech at home or abroad. The presidential regulation entered into force on the date of its expiration, i.e. on the same day by the Minister of Justice and Human rights Yasonna $\mathrm{H}$. Laoly. In this presidential regulation, the use of Bahasa Indonesia must meet the good and correct Bahasa Indonesia criteria. In accordance with the rules that include the rule of grammar, spelling rules, and rules of forming terms, as stipulated by the Ministerial Regulation.

According to the regulation, Bahasa Indonesia must be used in legislation, including word formation, sentence drafting, writing techniques and spelling. In the presidential decree, the Indonesian language must be used in the official documents of the State. Starting from the decree, securities, diplomas, certificates, identity letters, purchase deed, letter of appointment, and court ruling. "Bahasa Indonesia must be used in the official speeches of the President, Vice president, and other state officials who are delivered inside or outside the country," the sound of Article 5 of the Presidential Decree is quoted on the page setkab.go.id.

Then, affirmed in the Presidential Decree, delivering the official speech of the President or vice president in the National to International forum held in the country is done using Bahasa Indonesia. In Article 9 reads, the Unitary State Government of the Republic of Indonesia gives the same treatment in the use of language to head of state or head of government, deputy head of state or deputy head of government, Secretary General The United Nations, and/or the supreme Leader of an international organization that conducts official visits to Indonesia on the basis of State sovereignty, the principle of resicisity, and international customs.

According to this Presidential Decree, the President and Vice President and other state officials delivered an official speech in Bahasa Indonesia on the national forum at least including state ceremonies, celebrations ceremony August $17^{\text {th }}$ and other national holidays. Like the official ceremonies in the Council of national institutions, the delivery of the country's budget and expenditure plans or the regional budget and expenditure plans, and government work meetings or state high institutions as well as other national for the purpose of using Bahasa Indonesia. "In the event that it is necessary to clarify an understanding of the meaning of speech, the official speech of the President and/or Vice president, and other State officials submitted in Bahasa Indonesia may contain foreign language," the sound of article 15 Presidential Decree.

Then, in the regulation also written official speech of the President and Vice President abroad in the Forum held abroad conducted using Bahasa Indonesia. In the Presidential decree delivered in official forum held by the United Nations, international organizations, or recipient country. "Submission of the official speech of the President and/or Vice President as intended may be accompanied by or accompanied by a translator," article 18 of this Presidential Decree.

Furthermore, the Presidential Decree of the President and the Vice President can convey the contents of the speech as referred to orally in a foreign language and followed by a transcript of the speech in Bahasa Indonesia. According to this Presidential decree, the speech of the President and Vice President is not included as an official speech. The Presidential Decree also mentions that, in the event of need, the President and/or the vice President may deliver formal speeches in certain languages other than Bahasa Indonesia in international forums.

Certain languages as intended include the official language of the United Nations consisting of English, French, Chinese, Russian, Spanish, and Arabic, as well as other languages according to international law and customs. "Provisions on the official speech of the President and/or Vice 
President as intended to apply mutatis mutandis to the official speeches of other State officials in accordance with the degree of office and/or the Protocol of the protocols applicable to the officer the sound of article 22 of the Presidential Decree.

\section{B. Legal Aspect of Presidential Regulation (Bahasa Indonesia as National Language)}

Then if we speak about the legality aspects of state administration in the use of Indonesian presidential regulation review number 63 year 2019 itself that it can be related to the aspect of Government law in private law as a legal entity which affect the use of the name, the official language in each activity is both governmentowned and non-governmental legal entity, and also it can be related to the Government instruments in this case are from the decision of the State administration, policy rules, plans, licensing, and also the legal instrument of civil law (Ridwan, 2014: 86).

First is the Government law in private law as a legal entity, Countries, provinces, districts, and others in the perspective of civil law are referred to as public legal entities. The legal entity (Rechtspersoon) is a group of people, who are all in the life of society in accordance with the provisions of the Law can act as human beings, who have rights and authority, such as a group of people, Limited liability company, shipping companies, associations, and so on. If based on the public law of the country, province, and Regency is the department or group organization of the State and government organs, then based on the civil law of the state, the province, and the district is a collection of legal entities that Legal action is executed by the government.

When the government acts in the field of civil law and is subject to legal regulations, the government acts as a representative of the legal entity, not a representative of the office. Therefore, the position of government in the Association of Civil Law is no different to a person or private legal entity, has no special position, and can be a party to the civil dispute with the same position as Civil law (equality before the law) in a general judicial. In the exercise of authority, the Government is based on the existence of the legality principle where every action and authority of the Government must exist and in accordance with the laws and regulations exist, so that no malpractice of authority (Ridwan, 2014).
It also applies to government policy through Presidential Regulation Number 63 Year 2019 for use in every aspect of the activities for each State administration body. In this regulation also confirms, Bahasa Indonesia must be used in the name of a trademark that is a word or a combination of words owned by an Indonesian citizen or Indonesian legal entity. The use of Bahasa Indonesia on the trademark name as intended is excluded for the trademark which is a foreign license.

"In the case of trademarks referred to have historical, cultural, customs, and/or religious values, the name of the trademark may use regional language or foreign language," the sound of article 35 paragraph (3) of this Presidential decree. In addition, according to this regulation, Bahasa Indonesia must be used on behalf of a business institution established or owned by an Indonesian citizen or Indonesian legal entity. In the case of an Indonesian legal entity as referred to as limited liability company, according to this regulation, the obligation of the use of Bahasa Indonesia applies only to limited liability company whose share is owned by Indonesian citizen or legal entity Indonesian. "In the event that the business entity as intended has historical, cultural, customs, and/or religious values, the name of the business institution can use regional language or foreign language," the sound of article 36 paragraph (2) of this Presidential decree.

According to the regulation, in article 33 paragraph 1 of the Degree reads Bahasa Indonesia must be used in the name of buildings or buildings, apartments or settlements, offices, and trade complexes established or owned by Indonesian citizens or legal entities Indonesian.

Buildings or buildings, apartments or settlements, offices and trade complexes in question include: Hospitality, lodging, airport, port, terminal, station, factory, Tower, monument, Reservoir, DAM, Bendung, Tunnel, business place, public meeting place, entertainment venue, performance venue, sports complex, sports stadium, hospital, Housing, a stacking house, a burial complex, and other buildings or buildings. In the case of buildings or buildings, apartments or settlements, offices and trade complexes have historical, cultural, customs, and or religious values hence geographical name can use regional language or foreign language.

This regulation also mentions, Bahasa Indonesia must be used in public administration 
services in government agencies, at least used in: a. Communication between the organizer and public service receiver; b. Standards of public service; c. Service information; and d. Service information System. In case it is necessary to facilitate the understanding of public service recipients, according to this regulation, public administration services in government agencies can use regional language and/or foreign language as the equivalent or translation language Indonesian.

Added, Bahasa Indonesia must be used in official communication in government and private work environment. The official communication as intended, according to this regulation, is interemployee communication, interagency, and between institutions and communities related to the duties and functions of government and private institutions, conducted orally and or and may use electronic media. "Formal communication with international institutions or foreign institutions in a government and private work environment can use translators to assist in the smooth communication," The sound of article 29 of the Presidential decree.

Bahasa Indonesia, according to this regulation, must be used in a memorandum of understanding or agreement involving State institutions, government agencies of the Republic of Indonesia, Indonesian private institutions, or individuals of Indonesian citizens. "A memorandum of understanding or agreement involving a foreign party is also written in the national language of the foreign party and/or English, which is used as the equivalent or translation of Bahasa Indonesia to equate a memorandum of understanding or Agreements with foreign parties, "the sound of article 26 paragraph (3) of this Presidential decree. In the event of a discrepancy of interpretation of the equivalent or translation as referred to, according to this regulation, used is the language agreed in a memorandum of understanding or agreement.

\section{Declaration of Conflicting Interests}

The author state that there is no potential conflict of interest in the research, authorship, and/or publication of this article

\section{Funding}

None

\section{References}

Republic of Indonesia. (2009). Law Number 24 of
2009 concerning Flag, Language and Emblem
of the Country, and National Anthem.
Presidential Regulation Number 63 of 2019 about
the using of Bahasa Indonesia.
Sekretariat Kabinet Republik Indonesia.
https://setkab.go.id/ (Accessed 19 October
2019). Hukum Administrasi Negara. Jakarta:
Ridwan HR. Huaja
Penerbit PT Raja Grafindo Persada,
2014.

Republic of Indonesia. (2009). Law Number 24 of 2009 concerning Flag, Language and Emblem

hariat Kabinet Republik Indonesia.
https://setkab.go.id/ (Accessed 19 October

2014

Submitted February 23, 2020

Revision received March 18, 2020

Accepted April 23, 2020

\section{How to cite?}

Utama, M. A. R. (2020). Bahasa Indonesia as Official National Language: The Legal Aspect of Presidential Regulation Number 63 of 2019. Law Research Review Quarterly, 6(2), 185-188. https://doi.org/10.15294/Irrq.v6i2.37723 